\title{
Penekanan Penyakit Busuk Pangkal (Fusarium oxysporum f.sp. cepae) pada Bawang Merah oleh Beberapa Jenis Bahan Organik
}

\author{
Yudhisa Henry Prabowo ${ }^{1}$, Fitri Widiantini ${ }^{2}$, dan Noor Istifadah ${ }^{*}$ \\ ${ }^{1}$ Politeknik Pembangunan Pertanian, Manokwari, Papua Barat \\ ${ }^{2}$ Fakultas Pertanian, Universitas Padjadjaran \\ *Alamat korespondensi: n.istifadah@unpad.ac.id
}

\begin{abstract}
Supression of Basal Rot Disease (Fusarium oxysporum f.sp. cepae) in Shallot by Several Organic Materials
\end{abstract}

Basal rot disease caused by Fusarium oxysporum f.sp. cepae is an important disease in shallot plants. Organic materials are potential to be used for plant disease control. The aims of this study were to examine the abilities of organic materials (press mud, spent substrate of straw mushroom, rice-straw compost, and chicken manure) to suppress basal rot disease as well as support the growth and yield of shallot. The mechanisms involved in the pathogen inhibition were also evaluated in vitro. The greenhouse experiment was arranged in Randomized Block Design with 10 treatments and three replications. The treatments tested were the type of organic materials that were applied in planting holes with or without drenching of the plants with their teas every two weeks. The results showed that all organic materials tested suppressed the basal rot disease in shallot by $50.5 \%-63.2 \% \%$ as well as supported the growth and the shallot yield. The mechanism involved in the suppression of the pathogen was mostly due to the presence of microbes antagonistic to F. oxysporum f.sp. cepae. The microbes that showed the best inhibition (74.65\%) of the pathogen in vitro was Trichoderma sp. (MJ7) isolated from spent substrate of straw mushroom.

Keywords: Antagonistic microbe, Chicken manure, Press mud rice-straw compost, Spent mushroom substrate

\begin{abstract}
ABSTRAK
Busuk pangkal yang disebabkan oleh Fusarium oxysporum f.sp. cepae merupakan penyakit penting pada tanaman bawang merah. Bahan organik berpotensi untuk digunakan sebagai pengendali penyakit tanaman. Penelitian ini bertujuan untuk menguji kemampuan bahan organik (blotong, limbah jamur merang, kompos jerami, dan pupuk kotoran ayam) untuk menekan penyakit busuk pangkal serta pertumbuhan dan hasil pada bawang merah. Mekanisme yang terlibat dalam penekanan $F$. oxysporum f.sp. cepae secara in vitro juga dikaji. Percobaan di rumah kaca menggunakan Rancangan Acak Kelompok dengan 10 perlakuan dan tiga ulangan. Perlakuan yang diuji adalah jenis bahan organik yang diaplikasikan pada media tanam dengan atau tanpa penyiraman air rendamannya dua minggu sekali. Hasil percobaan menunjukkan bahwa semua bahan organik yang diuji dapat menekan penyakit busuk pangkal pada bawang merah sebesar 50,5\%-63,2\% serta mendukung pertumbuhan dan hasil bawang merah. Mekanisme penekanan $F$. oxysporum f.sp. cepae oleh bahan organik sebagian besar karena adanya mikrob yang dapat menghambat pertumbuhan patogen tersebut. Mikrob yang menunjukkan penghambatan terhadap patogen yang terbaik (74,7\%) adalah isolat MJ7 (Trichoderma sp.) yang berasal dari limbah jamur merang.
\end{abstract}

Kata Kunci: Blotong, Kotoran ayam, Kompos jerami, Limbah jamur merang, Mikrob antagonis 


\section{PENDAHULUAN}

Bawang merah merupakan komoditas hortikultura yang banyak dibutuhkan sebagai bumbu masakan dan bahan baku industri (Azzam, 2017). Bawang merah dapat dibudidayakan baik di dataran tinggi, medium atau dataran rendah (Kusmana dkk., 2009). Salah satu kendala dalam budidaya tanaman bawang merah adalah adanya penyakit tanaman (Udiarto dkk., 2005). Penyakit penting pada bawang merah yang dapat menimbulkan banyak kerugian, salah satunya adalah penyakit busuk pangkal atau dikenal juga dengan penyakit moler yang disebabkan oleh Fusarium oxysporum f.sp. cepae (Harz.) Snyd. \& Hans. Patogen ini menginfeksi pada pangkal batang, umbi dan menyebabkan daun menjadi kuning dan tampak terpelintir. Tanaman sangat mudah tercabut karena pertumbuhan akar terganggu bahkan membusuk (Semangun, 2007). Penyakit ini di beberapa sentra produksi bawang merah di Indonesia dapat menimbulkan kehilangan hasil sampai 50\% bahkan sampai menyebabkan gagal panen apabila lingkungan mendukung (Wiyatiningsih, 2007).

Pengendalian penyakit busuk pangkal atau moler pada tanaman bawang merah ini masih menekankan pada cara pengendalian dengan menggunakan pestisida. Namun demikian, penggunaan pestisida tidak selalu memberikan hasil yang memuaskan, bahkan dapat menimbulkan berbagai dampak merugikan bagi lingkungan. Penggunaan pestisida yang terus menerus juga dapat menimbulkan resistensi organisme pengganggu tanaman (OPT) (Mahmood et al., 2016).

Salah satu cara pengendalian yang aman terhadap lingkungan adalah dengan penggunaan bahan organik. Bahan organik dapat berfungsi sebagai pupuk organik dan juga berpotensi sebagai pengendali penyakit tanaman. Bahan organik diketahui dapat menekan berbagai penyakit yang disebabkan oleh berbagai patogen tular tanah (Mehta et al., 2014; Bonanomi et al., 2018). Pemberian bahan organik seperti kompos kotoran hewan dan kompos blotong (limbah pabrik gula) ke dalam tanah dapat menghambat pembentukan gall atau puru pada akar dan mengurangi populasi nematoda Meloidogyne incognita di dalam akar tanaman tebu (Rahayuningtyas dkk., 2010). Aplikasi pupuk kotoran ayam juga dapat menekan intensitas penyakit puru akar dan populasi J-2 Meloidogyne spp. pada tanaman cabai (Istifadah dkk., 2016) dan kedelai (Basuki dkk., 2014). Pupuk kotoran ayam juga dapat menekan penyakit karena Rhizoctonia solani pada rumput lapangan golf, Zoysia japonica (Pan et al., 2019).

Selain kompos dan kotoran ayam, bahan organik yang juga berpotensi dimanfaatkan untuk pengendalian penyakit tanaman adalah limbah media jamur merang. Aplikasi limbah jamur merang pada lubang tanam dan penyiraman air rendamannya dua minggu sekali juga dilaporkan dapat menekan penyakit busuk pangkal atau moler pada tanaman bawang merah (Yusidah \& Istifadah, 2018).

Mekanisme penekanan penyakit oleh bahan organik dapat dikarenakan adanya mikrob yang bersifat antagonistik terhadap patogen, senyawa yang dapat menghambat patogen dan induksi resistensi tanaman (Mehta et al., 2014; Bonanomi et al., 2018). Tujuan penulisan ini adalah untuk mengevaluasi kemampuan bahan organik yaitu blotong, limbah jamur merang, kompos jerami padi, dan pupuk kotoran ayam untuk menekan penyakit busuk pangkal, mendukung pertumbuhan dan hasil tanaman bawang merah di rumah kaca, serta mengevaluasi mekanisme yang terlibat dalam penghambatan patogen. Kemampuan mikrob asal bahan organik dalam menekan pertumbuhan $F$. oxysporum f.sp. cepae secara in vitro juga dikaji.

\section{BAHAN DAN METODE}

\section{Pengujian pada Tanaman bawang Merah di Rumah Kaca}

Penelitian menggunakan metode percobaan yang dibagi menjadi dua tahap yaitu percobaan di rumah kaca dan laboratorium. Percobaan di rumah kaca ditujukan untuk menguji kemampuan bahan organik dalam menekan penyakit busuk pangkal dan mendukung pertumbuhan serta hasil tanaman bawang merah. Percobaan ini menggunakan Rancangan Acak Kelompok dengan tiga ulangan. Perlakuan yang diuji adalah:

A : Kontrol

B : $\quad$ Cara Petani (pupuk urea dan NPK + dua jenis fungisida, mankozeb dan azokistrobin)

C : Aplikasi blotong Pada lubang tanam

D : Aplikasi limbah media jamur merang pada lubang tanam

E : Aplikasi pupuk kotoran ayam pada lubang tanam

F : Aplikasi kompos jerami pada lubang tanam

G: Aplikasi blotong pada lubang tanam + penyiraman air rendamannya 
H : $\quad$ Aplikasi limbah jamur pada lubang tanam + penyiraman air rendamannya

I : $\quad$ Pupuk kotoran ayam pada lubang tanam + penyiraman air rendamannya

J : Kompos jerami pada lubang tanam + penyiraman air rendamannya

Media tanam yang digunakan adalah tanah

Lembang (berjenis Andisol) yang telah dipasteurisasi (dikukus selama 5 jam). Media tanam sebanyak $15 \mathrm{~kg}$ dimasukkan ke dalam kotak plastik berukuran 50 x $30 \mathrm{~cm}$. Satu kotak berisi 15 umbi bawang merah varietas Bima Brebes dengan jarak tanam $10 \times 10 \mathrm{~cm}$.

Bahan organik diaplikasikan pada saat tanam, sebanyak $20 \mathrm{~g}$ per lubang tanam. Pada perlakuan dengan aplikasi susulan, bahan organik diaplikasikan dalam bentuk air rendamannya. Air rendaman bahan organik dibuat dengan mencampurkan bahan organik dan air dalam ember dengan perbandingan $1: 4$, (v/v), kemudian ember ditutup dan diinkubasikan selama satu minggu (Yusidah \& Istifadah, 2018). Air rendaman bahan organik tersebut disiramkan sebanyak $50 \mathrm{ml}$ per tanaman setiap dua minggu sekali yaitu mulai pada saat tanaman berumur dua minggu setelah tanam (MST). Biakan masal $F$. oxysforum f.sp. cepae pada medium beras diinokulasikan pada saat tanam sebanyak 5 g per lubang tanam.

Pada perlakuan pembanding (cara petani), fungisida berbahan aktif mankozeb diaplikasikan pada umbi sebelum ditanam yaitu dengan cara menaburkan bubuk fungisida pada umbi dengan dosis $1 \mathrm{~g} / \mathrm{kg}$ bibit. Selain itu, fungisida juga diaplikasikan pada saat tanaman berumur 2, 3, 4, 5, dan 6 minggu setelah tanam dengan cara menyemprotkan suspensi fungisida berbahan aktif mankozeb (konsentrasi 6 g/liter) dan azoksistrobin (konsentrasi $1 \mathrm{~g} /$ liter) pada pangkal batang tanaman. Pupuk sintetik yang digunakan adalah pupuk urea yang diaplikasikan pada saat tanam dengan dosis yang setara dengan $150 \mathrm{~kg} / \mathrm{ha}$ dan pupuk NPK yang dilakukan pada saat tanam dan dua minggu setelah tanam dengan dosis setara $300 \mathrm{~kg} / \mathrm{ha}$.

Pengamatan dilakukan terhadap kemunculan gejala untuk pertama kali yang dianggap sebagai masa inkubasi dan intensitas penyakit tanaman. Pengamatan intensitas penyakit dilakukan setiap dua minggu sekali sampai persentase kematian pada tanaman kontrol mencapai lebih dari 70\%. Perhitungan intensitas penyakit ditentukan dengan rumus (Chiang et al., 2017)

Keterangan:

$$
\mathrm{IP}=\frac{\Sigma(\mathrm{nxv})}{\mathrm{N} \times \mathrm{V}} \times 100 \%
$$

IP = intensitas penyakit (\%)/ keparahan penyakit

$\mathrm{n}=$ jumlah daun dari tiap kategori serangan

$\mathrm{v}=$ nilai skor tiap kategori serangan

$\mathrm{N}$ = banyaknya daun yang diamati

$\mathrm{V}=$ nilai skor serangan tertinggi

Skoring yang digunakan adalah:

$0=$ tidak ada gejala serangan

$1=0<\mathrm{x} \leq 20 \%$ jumlah daun yang bergejala

$2=20<\mathrm{x} \leq 40 \%$ jumlah daun yang bergejala

$3=40<\mathrm{x} \leq 60 \%$ jumlah daun yang bergejala

$4=60<\mathrm{x} \leq 80 \%$ jumlah daun yang bergejala

$5=80<\mathrm{x} \leq 100 \%$ jumlah daun yang bergejala

Variabel lain yang diamati adalah tinggi tanaman dan jumlah daun yang diamati setiap dua minggu sekali. Pada delapan minggu setelah tanam dilakukan pengamatan terhadap hasil umbi bawang merah berupa jumlah umbi, berat basah dan berat kering umbi. Penimbangan berat kering umbi bawang merah dilakukan terhadap hasil panen bawang merah yang telah dikeringkan di bawah sinar matahari selama seminggu.

\section{Percobaan secara In Vitro}

Percobaan secara in vitro dilakukan untuk menguji mekanisme yang terlibat dalam penekanan F. oxysforum f.sp. cepae oleh bahan organik apakah karena mikrob antagonis atau karena senyawa antimikrob. Percobaan dilakukan dengan menggunakan ekstrak air limbah baik yang sudah disterilkan maupun yang non steril. Percobaan menggunakan Rancangan Acak Lengkap dengan lima perlakuan dan lima ulangan.

Pengujian secara in vitro menggunakan air ekstrak dari bahan organik. Bahan organik dihaluskan dan ditambahkan aquades steril dengan perbandingan 1:4 (w/v), kemudian dihomogenkan dengan magnetic stirrer selama 10 menit. Suspensi sampel kemudian disentrifugasi dengan kecepatan 500 rpm selama 10 menit untuk mengendapkan partikel yang besar dan disentrifugasi kembali dengan kecepatan $1000 \mathrm{rpm}$ selama 10 menit. Supernatan yang diperoleh kemudian dipisahkan dari endapannya (El-Masry et al., 2011).

Air ekstrak dari limbah yang diuji dibagi menjadi dua yaitu ekstrak steril dan non steril. Air ekstrak bahan organik yang steril diperoleh setelah dilakukan sterilisasi terhadap ekstrak dengan 
menggunakan mikrofilter (ukuran pori 0,2 $\mu \mathrm{m}$ ). Air ekstrak bahan organik baik yang non steril maupun steril diuji efeknya terhadap pertumbuhan $F$. oxypsorum f.sp. cepae secara in vitro dengan metoda poisonous food (Dhingra \& Sinclair, 1995). Keterlibatan mikrob antagonis dalam penekanan penyakit dikaji dengan cara isolasi mikrob dari bahan organik dan pengujian kemampuannya dalam menghambat $F$. oxysporum f.sp. cepae secara in vitro dengan menggunakan metode dual culture (Dhingra \& Sinclair, 1995).

\section{Analisis Data}

Data hasil percobaan dianalisis secara statistik dengan menggunakan program SPSS versi 20. Data dianalisis dengan ANOVA dan bila hasilnya berbeda nyata dilanjutkan dengan Uji Lanjut Tuckey, HSD pada taraf nyata $5 \%$.

\section{HASIL DAN PEMBAHASAN}

Kemampuan Bahan Organik untuk Menekan Penyakit Busuk Pangkal

Pada percobaan di rumah kaca, gejala penyakit busuk pangkal baru mulai terlihat pada empat minggu setelah tanam (MST). Perlakuan dengan bahan organik yang diuji dapat menekan penyakit busuk pangkal pada bawang merah. Namun demikian, secara umum tingkat penekanan penyakitnya semakin lama cenderung menurun. Pada 8 MST, bahan organik dapat menekan penyakit busuk pangkal sebesar 50,5\%-63,2\%. Penekanan ini relatif lebih besar daripada perlakuan cara petani yang menggunakan pestisida (Tabel 1).

Pada 8 MST, intensitas penyakit busuk pangkal pada semua pelakuan dengan bahan organik tidak berbeda secara nyata (Tabel 1). Pada percobaan ini, bahan organik baik yang diaplikasikan sekali saja pada saat tanam ataupun yang diaplikasikan beberapa kali yaitu pada lubang tanam ditambah aplikasi susulan berupa penyiraman air rendamannya dua minggu sekali ternyata kemampuannya dalam menekan penyakit busuk pangkal tidak berbeda secara nyata.

Tabel 1. Intensitas penyakit busuk pangkal di tanaman bawang merah pada berbagai perlakuan bahan organik di rumah kaca

\begin{tabular}{|c|c|c|c|c|c|c|}
\hline \multirow[b]{2}{*}{ Perlakuan } & \multicolumn{6}{|c|}{ Intensitas penyakit (\%) } \\
\hline & $4 \mathrm{MST}$ & $\begin{array}{c}\text { Penekanan } \\
(\%)\end{array}$ & $6 \mathrm{MST}$ & $\begin{array}{c}\text { Penekanan } \\
(\%)\end{array}$ & $8 \mathrm{MST}$ & $\begin{array}{c}\text { Penekanan } \\
(\%)\end{array}$ \\
\hline A. Kontrol & $8,7 \mathrm{~b}$ & - & $24,0 \mathrm{c}$ & - & $63,3 \mathrm{~b}$ & - \\
\hline $\begin{array}{l}\text { B. Cara Petani (pupuk dan } \\
\text { fungisida sintetik) }\end{array}$ & $2,0 \mathrm{ab}$ & 76,9 & $12,7 \mathrm{ab}$ & 47,3 & $31,3 \mathrm{ab}$ & 50,5 \\
\hline C. Blotong pada lubang tanam & $0,7 \mathrm{a}$ & 92,3 & $5,3 \mathrm{ab}$ & 77,9 & 27,3 a & 56,8 \\
\hline $\begin{array}{l}\text { D. Limbah jamur merang pada } \\
\text { lubang tanam }\end{array}$ & $0,7 \mathrm{a}$ & 92,3 & $7,3 \mathrm{ab}$ & 69,5 & 28,7 a & 54,7 \\
\hline $\begin{array}{l}\text { E. Pupuk kotoran ayam pada } \\
\text { lubang tanam }\end{array}$ & $0,0 \mathrm{a}$ & 100,0 & $2,0 \mathrm{a}$ & 91,8 & 23,3 a & 63,2 \\
\hline F. Kompos jerami & $2,0 \mathrm{ab}$ & 76,9 & $6,0 \mathrm{ab}$ & 75,1 & $24,0 \mathrm{a}$ & 62,1 \\
\hline $\begin{array}{l}\text { G. Blotong di lubang tanam }+ \\
\text { penyiraman air rendamannya }\end{array}$ & $0,0 \mathrm{a}$ & 100,0 & $7,3 \mathrm{ab}$ & 69,5 & $27,3 \mathrm{a}$ & 56,8 \\
\hline $\begin{array}{l}\text { H. Limbah jamur pada lubang } \\
\text { tanam + penyiraman air } \\
\text { rendamannya }\end{array}$ & $0,7 \mathrm{a}$ & 92,3 & $8,7 \mathrm{ab}$ & 63,9 & $31,3 \mathrm{ab}$ & 50,5 \\
\hline $\begin{array}{l}\text { I. Pupuk kotoran ayam pada } \\
\text { lubang tanam + penyiraman air } \\
\text { rendamannya }\end{array}$ & $0,0 \mathrm{a}$ & 100,0 & $8,7 \mathrm{ab}$ & 63,9 & 25,3 a & 60,0 \\
\hline $\begin{array}{l}\text { J. Kompos jerami pada lubang } \\
\text { tanam + penyiraman air } \\
\text { rendamannya }\end{array}$ & $5,3 \mathrm{ab}$ & 38,5 & $6,7 \mathrm{ab}$ & 72,28 & 23,3 a & 63,2 \\
\hline
\end{tabular}


Kemampuan bahan organik untuk menekan penyakit dapat terjadi karena beberapa mekanisme antara lain bahan organik mengandung berbagai mikrob antagonis yang dapat menekan patogen, karena adanya senyawa metabolit sekunder baik yang dihasilkan mikrob atau hasil dari dekomposisi atau karena kemampuan bahan organik untuk meningkatkan ketahanan tanaman terhadap penyakit (Mehta et al., 2014; Bonanomi et al., 2018). Selain itu, bahan organik juga dapat meningkatan populasi dan aktivitas mikrob menguntungkan yang ada dalam tanah (Bonanomi et al., 2018).

\section{Pengaruh Bahan Organik terhadap Pertumbuhan dan Hasil Bawang Merah}

Hasil percobaan menunjukkan bahwa tinggi tanaman bawang merah pada semua perlakuan dengan bahan organik lebih baik daripada cara petani yang menggunakan pupuk sintetik (Tabel 2). Kemampuan bahan organik untuk mendukung pertumbuhan tanaman dikarenakan kandungan unsur haranya dan juga kemampuannya dalam memperbaiki sifat fisik dan biologi tanah (Saidy, 2018).

Tabel 2. Tinggi tanaman bawang merah diberbagai perlakuan bahan organik di rumah kaca

\begin{tabular}{|c|c|c|c|c|}
\hline \multirow{2}{*}{\multicolumn{2}{|c|}{ Perlakuan }} & \multicolumn{3}{|c|}{ Tinggi tanaman $(\mathrm{cm})$} \\
\hline & & 2 MST & 4 MST & 6 MST \\
\hline & Kontrol & $10,9 \mathrm{a}$ & 17,7 a & 21,9 a \\
\hline & Cara Petani (pupuk dan fungisida sintetik) & $13,4 \mathrm{ab}$ & $23,7 \mathrm{ab}$ & $29,4 \mathrm{ab}$ \\
\hline & Blotong pada lubang tanam & $19,4 \mathrm{bc}$ & $33,5 \mathrm{bc}$ & $41,1 \mathrm{c}$ \\
\hline & Limbah jamur merang pada lubang tanam & $17,9 \mathrm{bc}$ & $32,7 \mathrm{bc}$ & $39,4 \mathrm{bc}$ \\
\hline & Pupuk kotoran ayam pada lubang tanam & $19,4 \mathrm{bc}$ & $33,5 \mathrm{bc}$ & $40,1 \mathrm{bc}$ \\
\hline F. & Kompos jerami pada lubang tanam & $13,5 \mathrm{ab}$ & $27,7 \mathrm{abc}$ & $35,7 \mathrm{bc}$ \\
\hline G. & $\begin{array}{l}\text { Blotong pada lubang tanam + penyiraman air } \\
\text { rendamannya setiap dua minggu }\end{array}$ & $20,3 \mathrm{c}$ & $34,2 \mathrm{c}$ & $40,3 \mathrm{c}$ \\
\hline $\mathrm{H}$. & $\begin{array}{l}\text { Limbah jamur merang pada lubang tanam }+ \\
\text { penyiraman air rendamannya dua minggu sekali }\end{array}$ & $18,6 \mathrm{bc}$ & $33,2 \mathrm{bc}$ & $40,2 \mathrm{bc}$ \\
\hline I. & $\begin{array}{l}\text { Pupuk kotoran ayam pada lubang tanam }+ \\
\text { penyiraman air rendamannya dua minggu sekali }\end{array}$ & $19,7 \mathrm{bc}$ & $33,0 \mathrm{bc}$ & $39,7 \mathrm{bc}$ \\
\hline & $\begin{array}{l}\text { Kompos jerami pada lubang tanam + penyiraman air } \\
\text { rendamannya dua minggu sekali }\end{array}$ & $10,2 \mathrm{a}$ & $24,8 \mathrm{abc}$ & $32,5 \mathrm{abc}$ \\
\hline
\end{tabular}

Keterangan: nilai rata-rata dalam kolom yang diikuti dengan huruf yang sama tidak berbeda nyata menurut uji Tuckey HSD pada taraf $5 \%$.

Perlakuan yang cenderung lebih baik dalam mendukung pertumbuhan tanaman terutama tinggi tanaman adalah perlakuan dengan blotong (Tabel 2). Hasil penelitian lain juga menunjukkan bahwa aplikasi blotong dapat mendukung pertumbuhan tanaman. Pemberian blotong pada tanaman jagung secara nyata meningkatkan berat kering perakaran, $\mathrm{P}$ tersedia tanah, $\mathrm{pH}$ tanah, $\mathrm{C}$-organik dan $\mathrm{N}$ total tanah (Chairani, 2005). Aplikasi blotong juga dapat mendukung pertumbuhan bawang merah (Halifah et al., 2014). Jaya (2017) menyatakan bahwa pemberian blotong dengan dosis 20 ton/ha menghasilkan pertumbuhan dan hasil panen bawang merah terbaik dibandingkan kontrol dan cara petani yang menggunakan Urea, KCL, SP-36, ZA.

Semua bahan organik yang diuji juga mendukung pembentukan daun tanaman bawang merah. Jumlah daun pada perlakuan bahan organik tidak berbeda secara nyata bahkan ada yang lebih baik daripada perlakuan cara petani yang menggunakan pupuk anorganik. Pada percobaan ini, penyiraman tanaman dengan air rendaman bahan organik tidak meningkatkan efek bahan organik. Yusidah dan Istifadah (2018) juga melaporkan bahwa cara aplikasi bahan organik baik yang berupa padatan saja atau yang dikombinasikan dengan penyiraman air rendamannya tidak berpengaruh secara nyata terhadap kemampuan bahan organik dalam mendukung pertumbuhan.

Perlakuan yang cenderung mendukung pembentukan daun bawang merah relatif lebih baik pada 2, 4 dan 6 MST adalah perlakuan dengan limbah jamur merang dan pupuk kotoran ayam (Tabel 3). Kemampuan pupuk kotoran ayam dalam mendukung pertumbuhan tanaman bawang merah telah dilaporkan pada penelitian lain (Budianto dkk., 2015; Winanda dkk., 2019). Kemampuan limbah jamur merang untuk mendukung 
pertumbuhan bawang merah juga dilaporkan oleh Yusidah dan Istifadah (2018). Pada penelitian mereka, aplikasi limbah jamur merang baik pada lubang tanam saja maupun yang diberi susulan dengan penyiraman air rendamannya menghasilkan tinggi tanaman dan jumlah daun yang lebih baik daripada perlakuan dengan cara petani.

Tabel 3. Jumlah daun bawang merah pada berbagai perlakuan bahan organik di rumah kaca

\begin{tabular}{|c|c|c|c|c|}
\hline \multirow{2}{*}{\multicolumn{2}{|c|}{ Perlakuan }} & \multicolumn{3}{|c|}{ Jumlah daun per rumpun } \\
\hline & & 2 MST & $4 \mathrm{MST}$ & $6 \mathrm{MST}$ \\
\hline A. & Kontrol & $6,7 \mathrm{a}$ & 9,2 a & $11,2 \mathrm{a}$ \\
\hline & Cara Petani (pupuk dan fungisida sintetik) & $7,3 \mathrm{ab}$ & $12,1 \mathrm{ab}$ & $15,3 \mathrm{ab}$ \\
\hline & Blotong pada lubang tanam & $9,6 \mathrm{ab}$ & $15,8 \mathrm{ab}$ & $19,0 \mathrm{ab}$ \\
\hline & Limbah jamur merang pada lubang tanam & $10,1 \mathrm{~b}$ & $17,2 \mathrm{~b}$ & $22,7 \mathrm{c}$ \\
\hline & Pupuk kotoran ayam pada lubang tanam & $10,9 \mathrm{~b}$ & $17,4 \mathrm{~b}$ & $21,8 \mathrm{c}$ \\
\hline & Kompos jerami pada lubang tanam & $7,5 \mathrm{ab}$ & $14,5 \mathrm{ab}$ & $20,2 \mathrm{c}$ \\
\hline & $\begin{array}{l}\text { Kompos blotong pada lubang tanam + penyiraman air } \\
\text { rendamannya setiap dua minggu sekali }\end{array}$ & $10,2 \mathrm{ab}$ & $16,1 \mathrm{~b}$ & $19,4 \mathrm{ab}$ \\
\hline & $\begin{array}{l}\text { Limbah jamur merang pada lubang tanam + penyiraman air } \\
\text { rendamannya setiap dua minggu sekali }\end{array}$ & $9,9 \mathrm{ab}$ & $16,7 \mathrm{~b}$ & 20,6 c \\
\hline I. & $\begin{array}{l}\text { Pupuk kotoran ayam pada lubang tanam + penyiraman air } \\
\text { rendamannya dua minggu sekali }\end{array}$ & $9,8 \mathrm{ab}$ & $15,8 \mathrm{ab}$ & $20,1 \mathrm{c}$ \\
\hline J. & $\begin{array}{l}\text { Kompos jerami pada lubang tanam + penyiraman air rendamannya } \\
\text { dua minggu sekali }\end{array}$ & $6,6 \mathrm{a}$ & $12,8 \mathrm{ab}$ & $17,4 \mathrm{ab}$ \\
\hline
\end{tabular}

Aplikasi bahan organik yang diuji kecuali blotong dapat pula mendukung produksi umbi bawang merah. Berat kering simpan umbi bawang merah pada perlakuan bahan organik (kecuali blotong) secara nyata lebih tinggi daripada kontrol dan bahkan cenderung lebih tinggi daripada perlakuan cara petani (Tabel 4).

Tabel 4. Produksi umbi bawang merah pada berbagai perlakuan bahan organik

\begin{tabular}{|c|c|c|c|}
\hline Perlakuan & Berat basah $(\mathrm{g})$ & Berat kering (g) & Jumlah umbi \\
\hline A. Kontrol & $147,2 \mathrm{a}$ & $67,7 \mathrm{a}$ & $6,1 \mathrm{a}$ \\
\hline B. Cara Petani (pupuk dan fungisida sintetik) & $238,6 \mathrm{ab}$ & $108,1 \mathrm{ab}$ & $6,8 \mathrm{a}$ \\
\hline C. Blotong pada lubang tanam & $251,3 \mathrm{ab}$ & $99,4 \mathrm{ab}$ & $6,4 \mathrm{a}$ \\
\hline D. Limbah jamur merang pada lubang tanam & $324,4 \mathrm{~b}$ & $141,5 \mathrm{~b}$ & $6,1 \mathrm{a}$ \\
\hline E. Pupuk kotoran ayam pada lubang tanam & $311,8 \mathrm{~b}$ & $128,3 \mathrm{~b}$ & $6,9 \mathrm{a}$ \\
\hline F. Kompos jerami pada lubang tanam & $271,8 \mathrm{ab}$ & $117,4 \mathrm{~b}$ & $6,7 \mathrm{a}$ \\
\hline $\begin{array}{l}\text { G. Blotong + penyiraman air rendamannya dua } \\
\text { minggu sekali }\end{array}$ & $325,8 \mathrm{~b}$ & $138,9 \mathrm{~b}$ & 6,4 a \\
\hline $\begin{array}{l}\text { H. Limbah jamur merang + penyiraman air } \\
\text { rendamannya dua minggu sekali }\end{array}$ & $229,2 \mathrm{ab}$ & $114,3 \mathrm{ab}$ & $6,5 \mathrm{a}$ \\
\hline $\begin{array}{l}\text { I. Pupuk kotoran ayam + penyiraman air } \\
\text { rendamannya dua minggu sekali }\end{array}$ & $308,3 \mathrm{~b}$ & $135,9 \mathrm{~b}$ & 6,7 a \\
\hline $\begin{array}{l}\text { J. Kompos jerami + penyiraman air } \\
\text { rendamannya dua minggu sekali }\end{array}$ & $354,5 \mathrm{~b}$ & $136,3 \mathrm{~b}$ & $6,5 \mathrm{a}$ \\
\hline
\end{tabular}

Pada variabel jumlah umbi, ternyata semua perlakuan menunjukkan jumlah umbi yang tidak berbeda secara nyata. Tidak adanya perbedaan ini diduga disebabkan jarak tanam dan intensitas cahaya yang kurang ideal sehingga pembentukan umbi juga kurang optimal. Pada percobaan ini, bawang merah ditanam dalam kotak plastik berukuran $50 \mathrm{~cm}$ x 40 $\mathrm{cm}$ x $20 \mathrm{~cm}$, yang mana dalam satu kotak ditanam 15 
tanaman dengan jarak tanam $10 \times 10 \mathrm{~cm}$. Jarak tanam ini termasuk rapat. Menurut Budiastuti (2000) pada jarak tanam yang rapat, tanaman menjadi lebih tinggi dengan tajuk tanaman yang kecil serta kapasitas pengambilan unsur hara dan air juga menjadi berkurang. Pada tanaman bawang merah, hal ini dapat berpengaruh terhadap jumlah umbi bawang yang terbentuk.

Hasil percobaan ini menunjukkan bahwa bahan organik mampu menekan penyakit serta mendukung pertumbuhan dan hasil tanaman bawang merah. Pada percobaan ini, hasil umbi bawang merah pada perlakuan bahan organik relatif lebih baik dibanding cara petani. Hal ini kemungkinan karena bahan organik selain dapat menekan penyakit (Bonanomi et al., 2018), sebagai sumber unsur hara bagi tanaman, juga dapat memperbaiki struktur tanah (Saidy, 2018) sehingga lebih baik dalam mendukung pembentukan umbi.

\section{Penghambatan Pertumbuhan $F$. oxysporum f.sp. cepae oleh Bahan Organik secara in Vitro}

Bahan organik mampu mengendalikan penyakit tanaman, dapat karena adanya mikrob antagonis atau adanya senyawa toksik terhadap patogen (Mehta et al., 2014). Berdasarkan hal tersebut, maka dilakukan pengujian menggunakan ekstrak air dari bahan organik yang steril dan non steril (mengandung berbagai mikrob). Hasil pengujian menunjukkan ekstrak air non steril dari semua jenis bahan organik yang diuji menghambat pertumbuhan jamur $F$. oxysporum f.sp. cepae dengan tingkat penghambatan 79,78 - 89,25\% (Tabel 5). Adanya berbagai mikrob yang tumbuh pada medium yang diberi perlakuan ekstrak air bahan organik mengindikasikan bahwa penghambatan pertumbuhan patogen terjadi karena adanya kompetisi oleh mikrob yang ada pada bahan organik tersebut.

Pada perlakuan ekstrak air bahan organik yang telah disterilkan ternyata penghambatan pertumbuhan jamur F. oxysporum f.sp. cepae hanya terdapat pada perlakuan dengan pupuk kotoran ayam $(78,43 \%)$ dan blotong (84,5\%) (Tabel 5). Hal ini menunjukkan bahwa ekstrak air kedua bahan organik tersebut mengandung senyawa yang bersifat toksik terhadap patogen.

Tabel 5. Pengaruh limbah bahan organik terhadap pertumbuhan F. oxysporum f.sp. cepae secara in vitro

\begin{tabular}{lcccc}
\hline & \multicolumn{2}{c}{ Ekstrak non steril } & \multicolumn{2}{c}{ Ekstrak steril } \\
\cline { 2 - 5 } \multicolumn{1}{c}{ Perlakuan } & $\begin{array}{c}\text { Diameter } \\
\text { koloni } \\
\text { patogen } \\
(\mathrm{mm})\end{array}$ & $\begin{array}{c}\text { Penghambatan } \\
(\%)\end{array}$ & $\begin{array}{c}\text { Diameter } \\
\text { koloni } \\
\text { patogen } \\
(\mathrm{mm})\end{array}$ & $\begin{array}{c}\text { Penghambatan } \\
(\%)\end{array}$ \\
\hline Kontrol & $42,2 \mathrm{~b}$ & - & $42,2 \mathrm{~b}$ & - \\
Air ekstrak pupuk kotoran ayam & $8,5 \mathrm{a}$ & 79,8 & $9,1 \mathrm{a}$ & 78,4 \\
Air ekstrak kompos jerami padi & $7,1 \mathrm{a}$ & 83,1 & $41,5 \mathrm{~b}$ & 1,7 \\
Air ekstrak limbah jamur merang & $4,5 \mathrm{a}$ & 89,3 & $37,2 \mathrm{~b}$ & 11,8 \\
Air ekstrak blotong & $5,8 \mathrm{a}$ & 86,2 & $6,5 \mathrm{a}$ & 84,5 \\
\hline
\end{tabular}

Keterangan: nilai rata-rata dalam kolom yang diikuti dengan huruf yang sama tidak berbeda nyata menurut uji Tuckey HSD pada taraf 5\%.

Kemampuan air ekstrak dari pupuk kotoran ayam steril dalam menekan patogen kemungkinan karena kotoran ayam mengandung senyawa antimikrob. Pupuk kotoran ayam dapat mengandung residu antibiotik yang digunakan dalam beternak ayam. Antibiotik yang ditemukan pada pupuk kotoran ayam antara lain dari jenis fluoroquinolones, sulfonamides dan tetracyclines (Epps \& Blaney, 2016). Kemungkinan adanya kandungan antibiotik ini juga yang menyebabkan populasi dan variasi mikrob pada pupuk kotoran ayam relatif kecil (Tabel 6). Pada percobaan ini, air ekstrak dari kompos dan limbah jamur yang steril tidak efektif menekan $F$. oxysporum f.sp. cepae secara in vitro. Hal ini berarti penekanan penyakit oleh kedua bahan organik ini terjadi lebih karena keberadaan mikrob yang dapat menekan patogen daripada adanya senyawa yang bersifat toksik. Kedua bahan organik tersebut memang mengandung bakteri dan jamur yang jumlah maupun variasinya relatif tinggi (Tabel 6). Dari hasil isolasi mikrob dari bahan organik yang diuji, diperoleh 18 isolat jamur yang membentuk hifa atau miselia dan 23 isolat yang mempunyai koloni seperti bakteri. Bahan organik yang paling tinggi variasi jenis mikrobnya adalah limbah jamur merang. 
Tabel 6. Populasi dan jenis mikrob yang diperoleh dari bahan organik yang diuji

\begin{tabular}{llcccc}
\hline \multirow{2}{*}{ Bahan organik } & \multicolumn{2}{c}{ Populasi mikrob $(\mathrm{cfu} / \mathrm{g}$ tanah) } & \multicolumn{2}{c}{ Jumlah isolat } \\
\cline { 2 - 5 } & Bakteri & Jamur & Bakteri & Jamur \\
\hline A. & Kompos jerami padi & $6,5 \times 10^{6}$ & $6,5 \times 10^{5}$ & 7 & 4 \\
B. & Blotong & $15 \times 10^{6}$ & $4,5 \times 10^{6}$ & 4 & 4 \\
C. & Limbah jamur merang & $7,1 \times 10^{6}$ & $4,2 \times 10^{6}$ & 7 & 8 \\
D. & Pupuk kotoran ayam & $2,1 \times 10^{6}$ & $4,1 \times 10^{3}$ & 5 & 2 \\
\hline
\end{tabular}

\section{Kemampuan Mikrob Asal Bahan Organik untuk Menekan $F$. oxysporum f.sp. cepae}

Mengingat bahwa salah satu mekanisme yang terlibat dalam penekanan penyakit oleh bahan organik adalah keberadaan mikrob yang dapat menekan patogen, maka dilakukan pengujian terhadap jamur dan bakteri yang diisolasi dari bahan organik yang diuji. Hasil seleksi awal menunjukkan bahwa bahan organik yang diuji mengandung mikrob yang bersifat antagonistik terhadap patogen. Pada seleksi awal, di antara 18 isolat jamur yang diuji terdapat 7 isolat dari limbah jamur merang dan 4 isolat dari kompos menunjukkan penghambatan terhadap pertumbuhan $F$. oxysporum f.sp. cepae. Isolat-isolat ini diuji lebih lanjut untuk mengkonfirmasi kemampuannya menghambat patogen.
Jamur yang menunjukkan penghambatan terhadap F. oxysporum f.sp. cepae merupakan jamur dari genus Aspergillus, Trichoderma dan Penicillium.

Isolat yang paling baik dalam menghambat pertumbuhan $F$. oxysporum f.sp. cepae adalah jamur isolat MJ7 (Tabel 7). Berdasarkan karakteristiknya isolat tersebut adalah jamur Trichoderma sp. Kemampuan Trichoderma sp. sebagai jamur antagonis sudah banyak diketahui. Mekanisme antagonisme jamur Trichoderma sp. dapat berupa kompetisi, antibiosis dengan menghasilkan enzim B-(1-3) glukanase, kitinase dan senyawa yang bersifat toksik terhadap patogen seperti gliotoksin dan viridin (Saba et al., 2012). Pertumbuhan jamur Trichoderma yang cepat memungkinkan untuk mendiominasi media sehingga menghambat pertumbuhan patogen (Gambar 1).

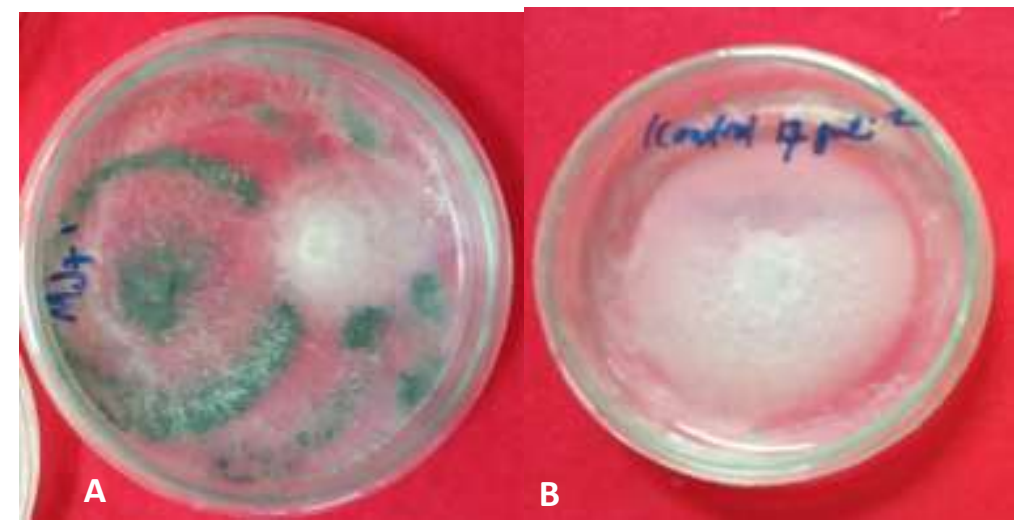

Gambar 1. Pertumbuhan patogen pada uji dual culture. A. Trichoderma sp. yang terdapat pada limbah jamur merang, B. Kontrol

Selain jamur yang membentuk hifa atau miselia, terdapat mikrob dengan koloni menyerupai bakteri yang dapat menghambat pertumbuhan $F$. oxysporum f.sp. cepae secara in vitro. Pada seleksi awal, di antara 23 isolat yang diperoleh, terdapat tiga isolat dari limbah jamur merang, empat isolat dari kompos dan satu isolat dari blotong yang menunjukkan adanya zona hambat terhadap pertumbuhan patogen yang diuji. Isolat-isolat ini diuji lebih lanjut kemampuannya untuk menghambat patogen. Pada uji lanjutan, isolat-isolat tersebut dapat menghambat $F$. oxysporum f.sp. cepae sebesar 43,4\%-62,91\%. Ada beberapa isolat yang pertumbuhannya melebar dengan cepat sehingga menghambat pertumbuhan jamur patogen. Selain itu, penghambatan juga terjadi karena terbentuknya zona bening atau zona hambat (Tabel 8). Kemampuan mikrob antagonis dalam membentuk zona bening terjadi karena mikrob tersebut menghasilkan metabolit sekunder yang dapat terdifusi ke dalam medium sehingga menghambat patogen. Mekanisme antagonisme ini 
dikenal sebagai antibiosis (Soesanto, 2013). Semua isolat yang diuji pada seleksi lanjutan ini dapat menghasilkan senyawa metabolit sekunder dengan kekuatan penghambatan yang berbeda-beda.

Penghambatan terbesar terhadap pertumbuhan koloni jamur F. oxysporum f.sp. cepae terdapat pada perlakuan dengan isolat KB1 yaitu mikrob yang berasal dari kompos (Tabel 8). Koloni isolat ini tampak tumbuh melebar serta menghasilkan zona hambat. Isolat yang dapat menghasilkan zona hambat yang relatif besar $(9,07$ $\mathrm{mm}$ ) adalah isolat MB1 yaitu mikrob dari limbah jamur merang (Gambar 2).

Tabel 7. Kemampuan jamur antagonis asal limbah bahan organik untuk menekan F. oxysporum f.sp. cepae

\begin{tabular}{llcc}
\hline \multicolumn{1}{c}{ Perlakuan } & \multicolumn{1}{c}{ Asal isolat } & $\begin{array}{c}\text { Jari-jari koloni } \\
\text { patogen }(\mathrm{mm})\end{array}$ & Penghambatan (\%) \\
\hline Kontrol & & $34,33 \mathrm{e}$ & 0 \\
MJ1 (Penicillium sp.) & limbah jamur merang & $17,5 \mathrm{~cd}$ & 49,0 \\
MJ2 (Aspergillius sp.) & limbah jamur merang & $12,5 \mathrm{abc}$ & 63,5 \\
MJ4 (Aspergillus sp.) & limbah jamur merang & $17,7 \mathrm{~cd}$ & 48,4 \\
MJ5 (Aspergilus sp.) & limbah jamur merang & $12,6 \mathrm{abc}$ & 63,3 \\
MJ6 (Aspergillus sp.) & limbah jamur merang & $15,1 \mathrm{abcd}$ & 56,0 \\
MJ7 (Trichoderma sp.) & limbah jamur merang & $8,7 \mathrm{a}$ & 74,7 \\
MJ8 (Trichoderma sp.) & limbah jamur merang & $9,2 \mathrm{ab}$ & 73,2 \\
KJ1 (Aspergillus sp.) & Kompos jerami padi & $16,0 \mathrm{bcd}$ & 53,3 \\
KJ2 (Aspergillus sp.) & Kompos jerami padi & $14,7 \mathrm{abcd}$ & 57,2 \\
KJ4 (Aspergillus sp.) & Kompos jerami padi & $18,9 \mathrm{~cd}$ & 44,9 \\
KJ7 (Aspergillus sp.) & Kompos jerami padi & 15,6 abcd & 54,6 \\
\hline
\end{tabular}

Keterangan: nilai rata-rata dalam kolom yang diikuti dengan huruf yang sama tidak berbeda nyata menurut uji Tuckey HSD pada taraf $5 \%$.

Tabel 8. Pertumbuhan F. oxysporum f.sp. cepae pada berbagai perlakuan isolat mikrob asal bahan organik

\begin{tabular}{lcccc}
\hline Perlakuan & Asal isolat & $\begin{array}{c}\text { Jari-jari koloni } \\
\text { patogen }(\mathrm{mm})\end{array}$ & $\begin{array}{c}\text { Penghambatan } \\
(\%)\end{array}$ & $\begin{array}{c}\text { Lebar zona } \\
\text { hambat }(\mathrm{mm})\end{array}$ \\
\hline Kontrol & Limbah jamur merang & $34,3 \mathrm{e}$ & 0,0 & - \\
MB1 & $19,3 \mathrm{ab}$ & 43,7 & $9,1 \mathrm{~b}$ \\
MB8 & Limbah jamur merang & $19,4 \mathrm{ab}$ & 43,4 & $8,3 \mathrm{~b}$ \\
MB9 & Limbah jamur merang & $17,0 \mathrm{a}$ & 50,6 & $8,6 \mathrm{~b}$ \\
AB3 & Kompos jerami padi & $16,7 \mathrm{a}$ & 51,4 & $2,4 \mathrm{a}$ \\
AB4 & Kompos jerami padi & $27,2 \mathrm{bc}$ & 20,7 & $2,9 \mathrm{a}$ \\
AB5 & Kompos jerami padi & $18.0 \mathrm{ab}$ & 47,7 & $3,3 \mathrm{a}$ \\
KB1 & Kompos jerami padi & $12,7 \mathrm{a}$ & 62,9 & $4,3 \mathrm{ab}$ \\
BB4 & Blotong & $19,7 \mathrm{ab}$ & 42,7 & $8,2 \mathrm{~b}$ \\
\hline
\end{tabular}

Keterangan: nilai rata-rata dalam kolom yang diikuti dengan huruf yang sama tidak berbeda nyata menurut uji Tuckey HSD pada taraf $5 \%$.
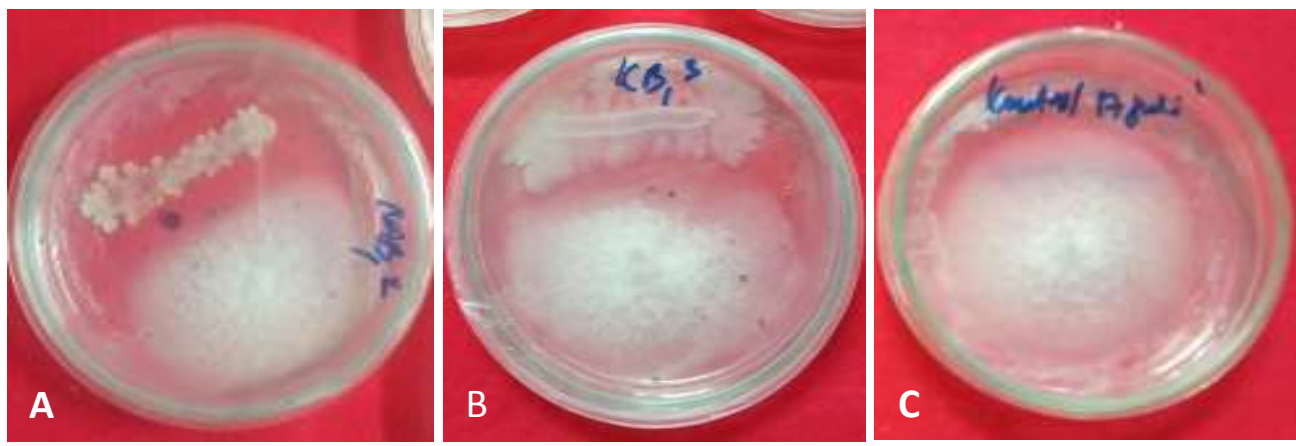

Gambar 2. Pertumbuhan F. oxysprorum f.sp. cepae pada perlakuan dengan isolat MB1 asal limbah jamur merang (A), isolat KB1 asal kompos (B) dan kontrol (C). 
Hasil percobaan secara in vitro menunjukkan bahwa kemampuan bahan organik dalam menekan penyakit busuk pangkal pada bawang merah dapat terjadi karena adanya mikrob antagonis atau karena adanya senyawa toksik terhadap patogen. Penekanan penyakit oleh limbah jamur merang dan kompos jerami lebih dikarenakan aktivitas mikrob antagonis. Jamur dan bakteri yang diisolasi dari kedua bahan organik tersebut banyak yang dapat menghambat $F$. oxsyprorum f.sp. cepae secara in vitro.

Penekanan penyakit karena pupuk kotoran ayam lebih dikarenakan adanya senyawa yang bersifat toksik terhadap $F$. oxsyprorum f.sp. cepae. Ekstrak air dari pupuk kandang yang sudah disterilkan dapat menghambat pertumbuhan patogen sebesar 78,4\% (Tabel 5). Selain itu, tidak ada satupun mikrob dari pupuk kotoran ayam yang dapat menghambat jamur patogen yang diuji.

Blotong dapat menekan penyakit busuk pangkal pada bawang merah karena adanya senyawa yang bersifat toksik terhadap patogen dan juga adanya mikrob antagonis. Ekstrak air dari blotong yang telah disterilkan dapat menghambat $F$. oxsyprorum f.sp. cepae sebesar 84,5\% (Tabel 5). Selain itu, ada juga isolat mikrob dari blotong yang dapat menghambat pertumbuhan patogen sebesar $42,7 \%$ dan menghasilkan zona hambat sebesar 8,2 $\mathrm{mm}$ (Tabel 8).

Hasil penelitian ini secara keseluruhan mengonfirmasi kemampuan bahan organik untuk menekan penyakit tanaman serta mendukung pertumbuhan dan hasil tanaman. Namun demikian, mengingat penekanan yang terjadi masih sekitar $50,5 \%-63,2 \%$, maka cara pengendalian ini dapat dikombinasikan dengan cara pengendalian lain misalnya dengan penggunaan mikrob antagonis yang telah diketahui kemampuannya. Isolat-isolat asal bahan organik yang berpotensi untuk menghambat pertumbuhan patogen dapat dikembangkan lebih lanjut sebagai agens pengendali biologi penyakit busuk pangkal.

\section{SIMPULAN DAN SARAN}

Berdasarkan hasil penelitian yang dilakukan dapat diambil simpulan sebagai berikut:

1. Bahan organik yang berupa blotong, limbah jamur merang, kompos jerami dan pupuk kotoran ayam dapat menekan penyakit busuk pangkal pada bawang merah ( $F$. oxysporum f.sp. cepae) pada pertanaman di rumah kaca dengan persentase penghambatan 50,5\% - 63,2\%.

2. Blotong dan limbah media jamur merang merupakan bahan organik yang paling baik dalam mendukung pertumbuhan (tinggi tanaman, jumlah daun) dan hasil (bobot umbi basah dan bobot umbi kering) tanaman bawang merah.

3. Penekanan $F$. oxysporum f.sp. cepae oleh bahan organik secara umum terjadi karena adanya mikrob yang bersifat antagonistik terhadap patogen. Isolat-isolat mikrob dari kompos jerami, limbah jamur merang dan blotong dapat menekan pertumbuhan $F$. oxysporum f.sp. cepae. Penekanan terbaik $(74,65 \%)$ terdapat pada isolat MJ7 yaitu jamur Trichoderma sp. yang berasal dari limbah jamur merang.

\section{Saran}

Saran yang dapat diberikan sebagai tindak lanjut penelitian ini antara lain:

1. Isolat-isolat mikrob yang dapat menghambat $F$. oxysporum f.sp. cepae perlu diteliti kemampuannya untuk menekan penyakit busuk pangkal pada tanaman bawang merah. Isolatisolat yang berpotensi juga perlu diidentifikasi lebih lanjut.

2. Perlu dilakukan pengujian kemampuan bahan organik yang diuji pada penelitian ini untuk menekan penyakit busuk pangkal dan mendukung pertumbuhan serta hasil tanaman bawang merah di lapangan.

\section{DAFTAR PUSTAKA}

Azzam. 2017. Budidaya Bawang Merah. Tersedia online pada http://mitalom.com/panduanteknis-budidaya-menanam-bawangmerah-dari-umbi-dimusim-hujan/azzam 2017. Diakses 10 Januari 2018.

Basuki, M Ali, dan Y Elfina. 2014. Pemberian beberapa jenis pupuk kandang untuk mengendalikan penyakit puru akar yang disebabkan oleh nematoda Meloidogyne spp. pada tanaman kedelai. Jurnal Online Mahasiswa Fakultas Pertanian Universitas Riau. 1(1): 1-12.

Bonanomi G, M Lorito, F Vinale, and SL Woo. 2018. Organic amendments, beneficial microbes, and soil microbiota: toward a unified framework for disease suppression. Annual Review of Phytopathology. 56(1): 1-20. 
Budianto, A, N Sahiri, dan IS Madauna. 2015.

Pengaruh pemberian berbagai dosis pupuk kandang ayam terhadap pertumbuhan dan hasil tanaman bawang merah (Allium ascalonicum L.) varietas Lembah Palu. E-J. Agrotekbis. 3 (4) :440-447.

Budiastuti, MS. 2000. Penggunaan Triakontanol dan Jarak Tanam pada Tanaman Kacang Hijau (Phaseolus radiatus 1.). Tersedia online pada http://www.iptek.net.id. Diakses 20 Desember 2019.

Chairani. 2005. Upaya pemanfaatan blotong sebagai pupuk untuk mengurangi pencemaran (studi kasus pemanfaatan pada tanaman jagung). Jurnal Penelitian Bidang Ilmu Pertanian. 3(3): 73-78.

Chiang KS, HI Liu, and CH Bock. 2017. A discussion on disease severity index values. Part I: warning on inherent errors and suggestions to maximise accuracy. Annals of Applied Biology. 171 (2): 139-154.

Dhingra, OB, and JB Sinclair. 1995. Basic Plant Pathology Methods. 2 ${ }^{\text {nd }}$ Edition. CRC Press. Boca Raton.

EL-Masry, MH, AI Khalil, MS Hassouna, and HAH Ibrahim. 2002. In situ and in vitro suppressive effect of agricultural composts and their water extracts on some phytopathogenic fungi. World Journal of Microbiology \& Biotechnology. (18): 551558.

Epps, AV, and L Blaney. 2016. Antibiotic residues in animal waste: occurrence and degradation in conventional agricultural waste management practices. Curr Pollution Rep. (2):135-155.

Halifah, NU, R Soelistyono, dan M Santoso. 2014. Pengaruh pemberian pupuk organik (blotong) dan pupuk anorganik (Za) terhadap tanaman bawang merah (Allium ascalonicum L.). Jurnal Produksi Tanaman. 2 (8): 665-672.

Istifadah, N, L Nurhasanah, BN Fitriatin, dan T Sunarto. 2016. Kemampuan formula biopestisida dan bahan organik untuk menekan penyakit bengkak akar (Meloidogyne spp.) pada tanaman cabai. Prosiding Seminar Nasional. Hlm. 546550.

Jaya, SP. 2017. Pengaruh Dosis Pupuk Organik Blotong terhadap Pertumbuhan dan Hasil Bawang Merah pada Tanah Pasiran.
[Tesis]. Universitas Mercu Buana. Yogyakarta.

Kusmana, R, S Basuki, dan H Kurniawan. Uji adaptasi lima varietas bawang merah asal dataran tinggi dan medium pada ekosistem dataran rendah Brebes. 2009. Jurnal Hortikultura. 19(3): 281-286.

Mahmood, I, SR Imadi, K Shazadi, A Gul, and KR Hakeem. 2016. Effects of pesticides on environment. In Pp. 254-269. Plant, Soil and Microbes. Vol. 1: Implications in Crop Science (KR Hakeem, MS Akhtar, SNA Abdullah, Eds.). Springer International. Switzerland.

Mehta, CM, U Palni, IH Franke-Whittle and AK Sharma. 2014. Compost: its role, mechanism and impact on reducing soilborne plant diseases. Waste Management. 34 (3): 607-22.

Pan, X, JD Mihail, RJ Kremer, and X Xiong. 2019. Fungistatic effect of a chicken manurebased organic fertilizer for suppression of a soilborne pathogen Rhizoctonia Solani Kühn. Journal of Soil and Plant Biology. 1: 61-72.

Rahayuningtyas, L Abadi, dan G Mujiono, G. 2010. Pengaruh penggunaan pupuk organik terhadap populasi nematoda parasit pada tanaman tebu (Saccharum officinarum L). Agritrop Jurnal Ilmu-Ilmu Pertanian. 8: 20-26.

Saba H, D Vibhash, M Manisha, KS Prashant, H Farhan, and A Tauseef. 2012. Trichoderma - a promising plant growth stimulator and biocontrol agent. Mycosphere. 3(4): 524531.

Saidy, AR. 2018. Bahan Organik Tanah: Klasifikasi, Fungsi dan Metode Studi. Lambung Mangkurat University Press. Banjarmasin.

Semangun, H. 2007. Penyakit-Penyakit Tanaman Holtikultura di Indonesia. Edisi kedua. Gadjah Mada University Press. Yogyakarta.

Soesanto, L. 2013. Pengantar Pengendalian Hayati Penyakit Tanaman. Edisi kedua. RajawaliPress. Jakarta. Hlm. 292 - 299.

Udiarto, BK, W Setiawati, dan E Suryaningsih. 2005. Pengenalan Hama dan Penyakit pada Tanaman Bawang Merah dan Pengendaliannya. Pusat Penelitian dan Pengembangan Hortikultura. ISBN: 9798034-48-9. 
Wahyudi, I. 2009. Serapan tanaman jagung (Zea mays L.) akibat pemberian pupuk guano dan pupuk hijau lamtoro pada ultisol wanga. J. Agroland. 16 (4): 265-272.

Winanda, A, E Efendi, dan Safruddin. 2019. Respon pemberian pupuk grower dan pupuk feses ayam terhadap pertumbuhan bawang merah. Bernas Agricultural Research Journal, 15(1): 41-53.
Wiyatiningsih, S. 2007. Studi Epidemi Penyakit Moler pada Bawang Merah. [Disertasi]. Program Studi Fitopatologi Universitas Gadjah Mada. Yogyakarta.

Yusidah, I, and N Istifadah. 2018. The abilities of spent mushroom substrate to suppress basal rot disease (Fusarium oxysporum f.sp. cepae) in shallot. International Journal of Biosciences. 13(1): 440-448. 